\title{
Individual autonomy as a moral trend in the context of a social crisis
}

\author{
Andrey Vladimirovich Mironov ${ }^{11}$, Lyudmila Nikolaevna Garas ${ }^{1}$, and Elena Nikolaevna \\ Maksimova $^{2}$ \\ ${ }^{1}$ Sevastopol State University, Institute of Social Sciences and International Relations, Department of \\ Political Sciences and Philosophy, Sevastopol, Russia \\ ${ }^{2}$ Sevastopol State University, Institute of Social Sciences and International Relations, Department of \\ International Relations and Foreign Regional Studies, Sevastopol, Russia
}

\begin{abstract}
The article analyzes the emergence of a philosophical problem of separating a person from the social world through the formation of an individual value model that presupposes an autonomous spiritual existence of an individual. The political and moral prerequisites of avoiding civic participation are considered. The study focuses on Seneca's moral theory, revealing the interaction of an individual with society in the context of the transformation of values during a social crisis. The goal of this study is 1) to determine the mutual influence between social inversions and changes in the value models of citizen behavior in society during a social crisis; 2) to formulate the main components of the concept 'individual autonomy', presented as part of the ancient tradition; 3) to specify and substantiate moral views of individual alienation from social community; and 4) to find out the features of this trend's development in the history of social philosophy. The method of historical and comparative analysis and the system method, which allows correlating historical facts and moral interpretations of social events proposed by the Roman authors, are used as a means of reaching the abovementioned goals. The evidence of interrelation between the ancient tradition and subsequent forms of individual autonomy is proposed. Forms of communication with society as part of the self-isolation model of an individual from social activities are presented. The moral contradiction between the official paradigm of morality and a personal perception of social reality is put forward as the basis of social isolation.
\end{abstract}

Keywords: autonomy, social alienation, moral crisis, internal independence

\section{Introduction}

The interaction of a man and society in the context of social distrust is due to the shift of the value system of the individual from socially significant goals to the sphere of personal interests that take on various forms of self-realization of the individual. Civil exclusion from problems experienced by the state poses a threat to national security, especially during

${ }^{1}$ Corresponding author: andreyvmironov@gmail.com 
periods of internal instability, as the unifying social principle containing resources for overcoming the crisis gets lost, and moral ethics based on a common worldview are replaced by a formal imitation of civil participation. Analysis of the philosophical tradition of individual autonomy contributes to the understanding of significant relationships between citizens (moral, social, and state), which determine the atmosphere in society at this stage of development. The experience of past thinkers provides an opportunity to highlight the conceptual vectors of social communication and use them as a means of overcoming social differences.

\section{$2 \quad$ Methods}

The goal of this study is 1) to determine the mutual influence between social inversions and changes in the value models of citizen behavior in society during a social crisis; 2) to formulate the main components of the concept 'individual autonomy', presented as part of the ancient tradition; 3) to specify and substantiate moral views of individual alienation from social community; and 4) to find out the features of this trend's development in the history of social philosophy.

The method of historical and comparative analysis and the system method, which allows correlating historical facts and moral interpretations of social events proposed by the Roman authors, are used as a means of reaching the abovementioned goals.

\section{Discussion and results}

The philosophical tradition of the perception of a person as a social being in ancient Greece was based on the need of society in an active civil process, the unification of private interests with universally significant aspirations of an ethnos. The collective orientation of a citizen's activity was justified by the idea of the common good containing the potential of personal growth (knowledge, moral self-perfection, and physical development). Patriotism was a unifying principle for citizens, it inherently contained conditions for self-realization of the individual, coinciding with the value model adopted by the majority. Avoidance of social duties was perceived as a violation of the moral duty to fellow men and served as the basis for censure and moral condemnation.

This trend is most fully represented in the works of Stoic thinkers: L.A. Seneca, M. Aurelius, Epictetus, whose writings correspond to the latent crisis of the Roman Empire. The transitional period from the republic, as a democratic form of government, to the authoritarianism of the imperial power, was characterized by a modification of the value models of citizen orientation in society. '... the Roman people, freedom of the people, a duty to serve Rome at all cost, at any place, and in any role - such was the basis of the value system of the Romans during the heyday of their city-state' [1]. Autocracy dictates a citizen a fundamentally different orientation of personal development.

Communication closeness is a consequence of the atmosphere of mistrust and suspicion established in the Roman Empire [2-4]. "All those who experienced any kind of failure or offense, all those who thought that society did not give them a good enough position, all restless, ambitious and dissatisfied rushed to take advantage of this opportunity (treason A.M.) to improve their position or to take revenge" [5]. A person's reputation depended on a set of external parameters: notoriety, possession of luxury and wealth, involvement in palace collisions, which were not of long duration and sustainability due to fierce competition for material benefits [6]. The emotional uncertainty of the individual in the social space creates the need to search for new ideals and a different way of existence as opposed to the generally accepted models of self-presentation [7]. In The Moral Letters to 
Lucilius Seneca proposes a theoretical summary of moral principles that would alter a person's lifestyle and thus make him/her less vulnerable to external circumstances (primarily social ones). He/she refuses to attempt social reforming, turning to the construction of an ideological model that involves changing the individual through a change in his/her attitude to the social world. In his opinion, the desire for independence and true freedom motivates a person to use previously unclaimed resources of individual consciousness: contemplation, inner concentration, and the ability to detach oneself.

On the basis of the proposed pattern of behavioral reactions to current events Seneca places a triad of values: political apathy, rationality, and simplicity, which were supposed to neutralize the impact of society values adopted in that period - power, social status, and wealth. Formation of self-sufficiency potential becomes the main task of a person, justified by the necessity of moral self-preservation.

Naturalness served Seneca as a worthy example of harmony and simplicity. 'Tell them what nature created as necessary and as superfluous, what easy laws it prescribed for us, and how pleasant it is to live following them, and how difficult and bitter it is to live for those who believe human opinion more than nature' (Seneca, 1986). Reason coordinated actions with the chosen way of life, its purpose in this model was to prevent a person from being dependent on the desires and needs cultivated by society. The ancient tradition of a sense of proportion, determined by thinking, had to correct the 'externally conditioned' and genuine needs. Therefore, the improvement and development of mental abilities was an integral part of the formation of an autonomous lifestyle.

In an autonomous state, a person perceives moral vices based on his/her own action rating system. The obvious discrepancy between the declared and the real state of morals in society contributes to the individual turning to the creation of his/her own model of communication in the moral sphere. The disposition toward wisdom, according to Seneca, contains immanently the means to overcome the vices and make the person free and happy, as he/she is guided not by someone else's instructions, but by consciously chosen moral tasks. Abstracting oneself from public opinion, the individual is brought closer to the probability of success in overcoming the egoistic limitation imposed by the prevailing public sentiments, and with the help of wisdom, determines the ways of his/her avoidance of evil life. Detachment from society while staying in it actualized the problem of forced social participation of a citizen in state affairs. The internal conflict resulting from the clash of imposed views and the desire to live virtuously develops into a universal rejection of social communication and into the minimization of contacts with it. "Epicurus teaches that a sage can engage in public life if it is required by its importance. Zeno, on the other hand, finds that a sage must engage in public life, unless there are particularly important obstacles to it" [8]. In Seneca's reasonings there are no nihilistic and anarchic tendencies, he recognizes the usefulness of the state as such, pays tribute to it for order and peace which it protects, but puts the right to choose to cooperate with society on a person. The accumulated wisdom as a result of a decent life outside of social passions helps to make the right decision. An important aspect for the formation of autonomous existence conditions is tolerance to opposing versions of behavioral standards. Getting rid of conflicts based on political and social predilections frees an individual consciousness from the feeling of cruelty, rigorism, fanaticism, thereby creating conditions for the realization of various forms of human existence in society.

The idea of a lifestyle independent of society in Stoic philosophy continued to generate in the cosmopolitan sphere [9]. A feeling of loneliness, resulting from the loss of national and social attachments, was to be balanced by a sense of individual happiness. Cosmopolitanism, according to Seneca, does not imply opposition to state patriotism, it should cause a person to concentrate on his/her own problems correlated with moral self-improvement. "After all, if external circumstances could reduce or increase virtue, then 
the honest would not be the only benefit. True benefits are all of the same weight and size" [8].

The tradition of individual autonomy in the social realm, as presented in antiquity, continues in the Christian world perception. Monasticism is a form of isolation from a distorted world, which blocks the true proximity of the Divine. The love of truth in this case is replaced by the love of God, which is attained by constant prayer and liberation from vices. Alienation from the secular and devoting oneself exclusively to faith implies concentration on inner experiences, moral redefinition of one's desires, which stimulates setting up a barrier between religious demands and public attitudes. Participation with the Divine (in the believer's eyes) motivates rejection of an imperfect social system, turning the individual to the need of reorganizing the life relationship model aimed at saving his/her own soul. The discrepancy in the criteria for evaluating actions in these areas dictates internal isolation from society and adherence to the selected moral principles [10, 11]. Separation from the technical civilization is embodied in the social movement of downshifting, where the autonomous existence model translates into practice. Rejection of competition and rivalry as the main forms of corporate communication in the bourgeois era and evaluation of the individual by society based on the achieved material success are manifested in the construction of an alternative life model. Emphasis is placed on tranquility, affinity with nature, and free labor [12-15].

\section{Conclusion}

The cause of this phenomenon is the transformation of the old traditions of social existence into qualitatively new forms that lost the basic values of joint social activities. A common feature of alienation from society throughout history was the individual's reconsidering of the value system that developed in society, above all, the moral component of public communication. The crisis phenomena experienced by the state immanently contain a prerequisite for the search of alternative ways of self-realization. An autonomous existence can be considered a result of the formalized relations proposed by society that do not contain a common value basis. An appeal to philosophical context is caused by searching for an antithesis to unacceptable social stereotypes. The need to make independent decisions is justified by the discrepancy with the proposed forms of self-realization, which motivates the individual to form personally significant criteria for assessing himself/herself and the world, choosing a different life path.

\section{References}

1. E.M. Shtaerman, Krizis antichnoi kultury [The Crisis of Ancient Culture] (Nauka Press Publ., Moscow, 1975)

2. G.T. Suetonius, Zhizn dvenadtsati Tsezarei [The Twelve Caesars] (Pravda Publ., Moscow, 1988)

3. S.L. Utchenko, Yulii Tsezar [Julius Caesar] (Mysl Publ., Moscow, 1976)

4. R.Yu. Wipper, Bul. Ancient Hist. 1, 43-63 (1948)

5. G. Boissier, Kartiny rimskoi zhizni vremen tsezarei [Pictures from Roman Life in the Days of the Caesars] (N.P. Karbasnikov Publ., Moscow, 1915)

6. J.N. Robert, Povsednevnaya zhizn drevnego Rima cherez prizmu naslazhdenii [Everyday life of Ancient Rome through the Prism of Pleasure] (Molodaya Gvardiya Publ., Moscow, 2006) 
7. M. Goerger, Comp. Philos. 8(1), 47-62 (2017). https://doi.org/10.31979/2151-6014(2017).080107

8. L.A. Seneca, Nravstvennye pisma k Lutsiliyu [Letters to Lucilius] (Kemerovo Publ., Kemerovo, 1986)

9. J.L. Zainaldin, Clas. Philol. 114(2), 218-237 (2019). https://doi.org/10.1086/702639

10. G.V. Florovsky, Vostochnye ottsy tserkvi [Eastern Church Fathers] (AST Publ., Moscow, 2005)

11. L. Regnault, Povsednevnaya zhizn ottsov-pustynnikov IV veka [The Daily Life of the Hermits of the $4^{\text {th }}$ Century] (Molodaya Gvardiya Publ., Moscow, 2008)

12. C. Breakspear, C. Hamilton, Disc. Paper 62 (2004)

13. S.N. Ermakova, Monit. Pub. Opinion 6, 97-106 (2012)

14. C. Hamilton, Disc. Paper 58 (2003)

15. G.D. Thoreau, Vysshie zakony [Supreme Law] (Respublika Publ., Moscow, 2001) 